\title{
Characterization of pectin lyase produced by an endophytic strain isolated from coffee cherries
}

\author{
C.C.H. Sakiyama, E.M. Paula, P.C. Pereira, A.C. Borges and D.O. Silva \\ Departamento de Microbiologia, BIOAGRO, Universidade Federal de Viçosa, MG, Brazil
}

2000/76: received 11 May 2001 and accepted 11 May 2001

C.C.H. SAKIYAMA, E.M. PAULA, P.C. PEREIRA, A.C. BORGES AND D.O. SILVA. 2001.

Aims: The effect of endophytic bacterial activity on the quality of coffee beverage was studied.

Methods and Results: A survey of the micro-organisms in coffee cherries was performed

before harvesting, and their growth on the main nutrients available in coffee cherries was

determined in vitro.

Conclusions: Many endophytic bacteria were isolated from surface-sterilized coffee cherries.

One of the pectinolytic strains was physiologically and phenotypically characterized, and was tentatively identified by partial $16 \mathrm{~S}$ rDNA sequencing as Paenibacillus amylolyticus. This endophytic strain produced an extracellular pectinase with maximal activity at $40^{\circ} \mathrm{C}$ and $\mathrm{pH} 7 \cdot 9$, and was thermostable up to $45^{\circ} \mathrm{C}$. EDTA and metal ions had little effect on pectin lyase activity. $\mathrm{K}_{\mathrm{m}}$ and $\mathrm{V}_{\max }$ values were $4.6 \mathrm{mg} \mathrm{ml}^{-1}$ and $94 \cdot 010^{-8} \mathrm{~mol} \mathrm{~min}^{-1} \mathrm{ml}^{-1}$, respectively.

Significance and Impact of the Study: Pectin lyases have been found in fungi but rarely in bacteria, and this isolate is a promising tool for regulation studies of these enzymes.

\section{INTRODUCTION}

Endophytic bacteria are defined as those bacteria that can be isolated from surface-disinfected plant tissue or extract from within the plant, but which do not visibly harm the plant (Hallmann et al. 1997). Endophytes may have several beneficial effects in host plants and are used in the biological control of plant pathogens, for enhancing agronomic plant characteristics such as increased drought tolerance and nitrogen efficiency, as bioherbicides, and as pharmacological agents (Bacon and Hinton 1997).

Besides invading plants through natural openings or wounds, endophytic bacteria appear actively to penetrate plant tissues using hydrolytic enzymes such as cellulase and pectinase (Reinhold-Hurek and Hurek 1998). Numerous endophytic bacteria, such as Azoarcus sp. (Hurek et al. 1994) and Pseudomonas fluorescens (Quadt-Hallmann et al. 1997), produce pectinolytic enzymes.

Pectinases have widespread applications in the food and textile industries (Alkorta et al. 1998; Henriksson et al. 1999). Among the known pectinases, pectin lyase (E.C. 4.2.2.10)

Correspondence to: Dr D.O. Silva, Departamento de Microbiologia, BIOAGRO, Universidade Federal de Viçosa, 36571-000 Viçosa, Minas Gerais, Brazil.
(PL) is the only pectic enzyme that can cleave the $\alpha-1,4$ bonds of highly esterified pectins without prior action of other enzymes (Alanã et al. 1991). This enzyme is thus well suited for de-gumming of natural fibres (Baracat-Pereira et al. 1994), plant tissue maceration and fruit juice wastewater treatment (Kashyap et al. 2000). Pectin lyase is commonly produced by fungi (Prade et al. 1999) and is also produced by some bacteria, such as Bacillus spp. (Kashyap et al. 2000) and Pseudomonas marginalis (Hayashi et al. 1997).

Endophytic bacteria are ubiquitous in most plant species. Despite the importance of coffee in agricultural economies, the only reported endophytic bacterium isolated from coffee to date is Acetobacter diazotrophicus, which was isolated from roots and stems (Jimenez-Salgado et al. 1997). It is believed that the present work is the first record of isolation of an endophytic bacterium from healthy coffee cherries. This is also the first report of pectin lyase production by a strain of Paenibacillus amylolyticus.

\section{MATERIALS AND METHODS}

\section{Media and cultural conditions}

Nutrient broth and nutrient agar were used for isolation and culturing. A solid mineral medium containing: $7 \cdot 0 \mathrm{~g} \mathrm{l}^{-1}$ 
$\mathrm{K}_{2} \mathrm{HPO}_{4} ; 2 \cdot 0 \mathrm{~g} \mathrm{l}^{-1} \mathrm{KH}_{2} \mathrm{PO}_{4} ; 1 \cdot 0 \mathrm{~g} \mathrm{l}^{-1}\left(\mathrm{NH}_{4}\right)_{2} \mathrm{SO}_{4} ; 1 \cdot 1 \mathrm{~g} \mathrm{l}^{-1}$ $\mathrm{MgSO}_{4} .7 \mathrm{H}_{2} \mathrm{O} ; 1.5 \mathrm{~g} \mathrm{l}^{-1}$ agar, at $\mathrm{pH} 7 \cdot 0$, enriched with $0.6 \mathrm{~g}^{-1}$ yeast extract and $3 \mathrm{~g} \mathrm{l}^{-1}$ citric pectin (Sigma) as the sole carbon source, was used for selection of pectinolytic strains. Basal medium (BM) containing $7 \cdot 0 \mathrm{~g} \mathrm{l}^{-1} \mathrm{~K}_{2} \mathrm{HPO}_{4}$; $2.0 \mathrm{~g} \mathrm{l}^{-1} \mathrm{KH}_{2} \mathrm{PO}_{4} ; 1.0 \mathrm{~g} \mathrm{l}^{-1}\left(\mathrm{NH}_{4}\right)_{2} \mathrm{SO}_{4} ; 1.1 \mathrm{~g} \mathrm{l}^{-1} \mathrm{MgSO}_{4} .7-$ $\mathrm{H}_{2} \mathrm{O}$; and $0.6 \mathrm{~g} \mathrm{l}^{-1}$ yeast extract, at $\mathrm{pH} 7 \cdot 0$, was used to verify the utilization of different carbon sources to aid in the characterization of the pectinolytic isolate. For these studies, $3 \mathrm{~g} \mathrm{l}^{-1}$ of each carbon source was added to the BM. To establish pectinolytic isolate vitamin requirements, yeast extract was omitted from the $\mathrm{BM}$ and $50 \mathrm{mg} \mathrm{l}^{-1}$ of each vitamin (thiamin, calcium pantothenate, riboflavin and pyridoxine) was added. For enzyme assays, the isolate was cultured in BM enriched with $3 \mathrm{~g} \mathrm{l}^{-1}$ citric pectin (Sigma). Bacteria were grown at $25^{\circ} \mathrm{C}$ on a rotary shaker $(150 \mathrm{rev}$ $\left.\min ^{-1}\right)$.

\section{Sampling and surface sterilization}

Ripe cherries from coffee plant (Coffea arabica L.) cultivar Catuaí Vermelho, grown under field conditions, were collected in Araponga, Minas Gerais, Brazil. The samples were maintained at $4^{\circ} \mathrm{C}$ until processing. Individual cherry samples were pre-washed in running tap water, brushed with soapy water and rinsed thoroughly in tap water. All subsequent steps were performed aseptically. The cherries were shaken twice on a rotary shaker in sterile tap water and once in sterile $0.05 \mathrm{~mol} \mathrm{l}^{-1}$ potassium phosphate buffer, pH 7.0 (PB). Cherry samples were surface-sterilized by immersion in $70 \%$ ethanol for $1 \mathrm{~min}$, soaked for 5 min under vigorous shaking in 5\% sodium hypochlorite containing $0.01 \%$ Tween 80 , and then flamed after immersion in $70 \%$ ethanol for $30 \mathrm{~s}$. Cherries were then left in sterile PB for $15 \mathrm{~min}$ and the sterilization steps described above were repeated. Finally, the cherry samples were rinsed four times in sterile distilled water. Surface sterility was checked by incubating each cherry sample in a test tube containing $10 \mathrm{ml}$ nutrient broth for $72 \mathrm{~h}$. Test tubes in which growth occurred were discarded.

\section{Isolation and preservation of endophytes}

The surface-sterilized ripe coffee cherries were opened aseptically and the coffee beans were incubated in nutrient broth for $96 \mathrm{~h}$. Endophytes were isolated from tubes showing growth on nutrient agar. Bacterial isolates were randomly selected from single colonies and re-streaked until pure cultures were obtained. Individual strains were cultured for $18-24 \mathrm{~h}$ in nutrient broth and maintained at $-80^{\circ} \mathrm{C}$ on a nutrient broth $/ 30 \%$ glycerol mix.

\section{Pectinolytic strain characterization}

Colony morphology and pigment production on nutrient agar were observed after $24 \mathrm{~h}$ of growth. Cell shape and spore formation were determined by Gram staining. Gram characterization was confirmed by the presence of L-alanine aminopeptidase in the cell wall (Bactident reagent, Merck). Motility was observed by the hanging-drop method (Murray et al. 1994). Catalase activity was determined by bubble production in a $3 \%(\mathrm{v} / \mathrm{v}) \mathrm{H}_{2} \mathrm{O}_{2}$ solution. Oxidase production was determined by oxidation of $p$-aminodimethylaniline dihydrochloride (Bacto oxidase strips). Casein, starch, and esculin hydrolysis, nitrate reduction, phenylalanine deamination, citrate and malonate utilization, acetylmethylcarbinol and indole production, and carbohydrate fermentation, were evaluated according to Smibert and Krieg (1994). Hydrogen sulphide production was verified on triple sugar iron agar (Merck). Further physiological characterization was carried out by evaluating utilization of cellobiose, cellulose, fructose, galactose, glucose, lactose, maltose, mannose, pectin, ribose, starch, sucrose, xylose, casein or hydrolysed casein as sole carbon sources.

The pectinolytic strain was tentatively identified by phylogenetic analysis of a partial $16 \mathrm{~S} \mathrm{rDNA}$ sequence at Fundação André Tosello, Campinas, Brazil (http://www. fat.org.br). A $16 \mathrm{~S}$ rDNA gene fragment was amplified by PCR with $\mathrm{p} 27 \mathrm{f}$ and $\mathrm{p} 1525 \mathrm{r}$ primers, homologous to conserved regions of bacterial $16 \mathrm{~S}$ rRNA genes. Purified $16 \mathrm{~S}$ rDNA fragments were used as sequencing templates. Sequencing was carried out using a model ALFexpress automatic DNA sequencer (Pharmacia, Uppsala, Sweden). The sequencing primers were $10 \mathrm{f}$ (forward) and $765 \mathrm{f}$ (forward), which are internal primers to the $16 \mathrm{~S}$ rRNA gene. The partial $16 \mathrm{~S}$ rDNA sequence was aligned with previously published 16S rRNA gene sequences obtained from the GenBank and RPD (Ribossomal Database Project) databases. Distance matrices were calculated according to the Jukes-Cantor model (Jukes and Cantor 1969). Construction of a neighbor-joining phylogenetic tree was done according to Saitou and Nei (1987).

\section{Enzyme assay}

Pectin lyase activity was determined spectrophotometrically $\left(A_{235}\right)$, according to Albersheim (1966), in the culture supernatant fluid harvested at the end of the $\log$ phase of growth. The reaction mixture consisted of $1.0 \mathrm{ml} 2.5 \%$ citric pectin (Sigma), apple pectin (Sigma) or polygalacturonic acid (Sigma) in $80 \mathrm{mmol} \mathrm{l}^{-1}$ phosphate buffer ( $\left.\mathrm{pH} 6 \cdot 8\right)$ and $1.5 \mathrm{ml}$ culture supernatant fluid. Aliquots of $0.5 \mathrm{ml}$ of the reaction mixture were added to $4.5 \mathrm{ml} 0.01 \mathrm{~N} \mathrm{HCl}$ at 0 and 20 min of incubation at $40^{\circ} \mathrm{C}$. One unit of PL activity 
unit (U) was defined as nanomoles of unsaturated uronides formed per millilitre of culture supernatant fluid per minute. Polygalacturonase (PG) activity was measured spectrophotometrically $\left(\mathrm{A}_{540}\right)$, using polygalacturonic acid as substrate and 3,5-dinitrosalicylic acid and $\mathrm{D}(+)$ galacturonic acid as standards (Miller 1959). Pectate lyase (PAL) activity was determined spectrophotometrically $\left(A_{230}\right)$ using polygalacturonic acid as substrate (Moran et al. 1968). The pH of maximum PL activity was determined using sodium/ acetate/potassium phosphate/Tris buffer, at a final concentration of $50 \mathrm{mmol} \mathrm{l}^{-1}$, in the $\mathrm{pH}$ range of $3 \cdot 5-10 \cdot 5$. The culture supernatant fluid was dialysed (membrane MWCO 12-14 000, Spectrum, Houston, TX, USA) for pH determination, and for evaluation of EDTA and metal ion effects on PL activity.

\section{RESULTS}

\section{Isolation and characterization of pectinolytic strain}

Among the endophytic and pectinolytic bacteria isolated from ripe, healthy coffee cherries, isolate $F$ 7-4 produced the greatest hydrolysis zone in solid medium, and was further characterized.

Isolate F 7-4 produced extracellular PL but not extracellular PAL or PG. It was a facultatively anaerobic, motile and Gram-positive bacterium. Cells were rod-shaped, with cylindrical spores in swollen sporangia. The cells were Gram-negative at early stages of growth but became Grampositive as the culture aged. Cell-wall L-alanine aminopeptidase was absent. Colonies were flat, smooth and circular. No soluble pigment was produced on nutrient agar. Isolate F $7-4$ had catalase activity but no oxidase activity. Casein, starch and esculin were hydrolysed. Nitrate was reduced to nitrite. Phenylalanine was not deaminated. Citrate and malonate were not utilized. Acetylmethylcarbinol, indole and hydrogen sulphide were not produced. Acid, but no gas, was produced from D-glucose. Isolate F 7-4 utilized cellobiose, cellulose, fructose, galactose, glucose, lactose, maltose, mannose, pectin, ribose, starch, sucrose and xylose as carbon sources. Neither casein nor hydrolysed casein was used as sole carbon source. However, the casein hydrolysis test was positive. Isolate $\mathrm{F} 7-4$ required yeast extract as a growth promoter in $\mathrm{BM}$ when glucose or pectin was used as sole carbon source. It also showed growth when thiamin, riboflavin, calcium pantothenate or pyridoxine replaced yeast extract.

The partial 16S rDNA sequence of isolate F 7-4 showed $96 \%$ similarity to the $16 \mathrm{~S}$ rDNA sequence of Paenibacillus amylolyticus and $90-95 \%$ similarity to the $16 \mathrm{~S}$ rDNA sequences of $P$. pabuli, $P$. macquariensis and $P$. lautus strains. Phylogenetic analysis (Fig. 1) grouped isolate F 7-4 with the P. amylolyticus type strain (Nakamura 1984; Ash et al. 1994 emend; Shida et al. 1997). Phenotypic characteristics were in good agreement with those described by Shida et al. (1997) for P. amylolyticus. Isolate F 7-4 has been deposited as Paenibacillus amylolyticus CCT7128 at Coleção de Culturas Tropical, Fundação André Tosello, Campinas, Brazil.

\section{Pectin lyase properties}

Pectin lyase from isolate $\mathrm{F}$ 7-4 catalysed the cleavage of pectin from different sources, but was more active with citric pectin than apple pectin and showed little activity with polygalacturonic acid (Table 1). Maximal PL activity was observed at $40^{\circ} \mathrm{C}$ and the enzyme was fully thermostable up to $45^{\circ} \mathrm{C}$. Above this temperature, activity was quickly lost and

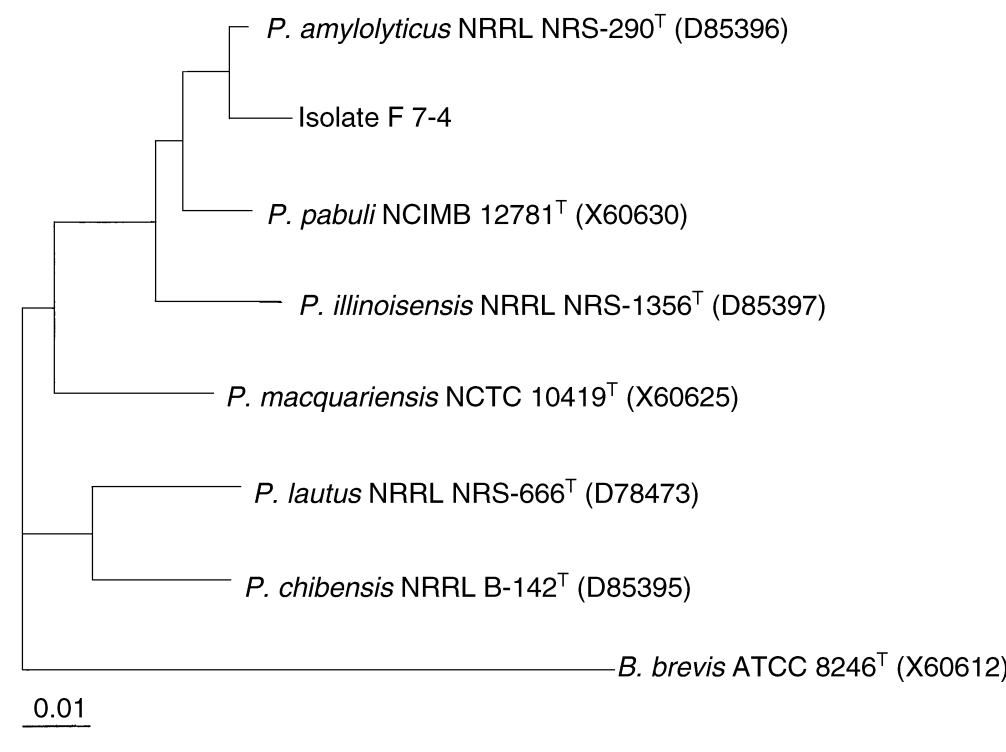

P. macquariensis NCTC $10419^{\top}$ (X60625)

Fig. 1 Phylogenetic tree based on the alignment of 16S rRNA partial sequence of isolate F 7-4 and Paenibacillus amylolyticus, P. chibensis, $P$. illinoisensis, P. lautus, P. macquariensis and $P$. pabuli. Brevibacillus brevis was used as an out-group. Accession numbers between parenthesis are from GenBank database

(c) 2001 The Society for Applied Microbiology, Letters in Applied Microbiology, 33, 117-121 
Table 1 Substrate specificity of isolate F 7-4 pectin lyase

\begin{tabular}{lc}
\hline Substrate at $1 \%(\mathrm{w} / \mathrm{v})^{*}$ & Relative activity $(\%) \dagger$ \\
\hline Pectin (citrus) & 100 \\
Pectin (apple) & 39 \\
Polygalacturonic acid & 4 \\
\hline
\end{tabular}

*In $80 \mathrm{mmol} \mathrm{l}^{-1}$ potassium phosphate buffer, $\mathrm{pH} 6 \cdot 8$.

$\dagger$ Activity was measured using the standard assay procedure.

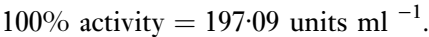

Table 2 Effect of EDTA and metal ions on isolate $\mathrm{F} 7-4$ pectin lyase activity

\begin{tabular}{lcc}
\hline Compound* & $\begin{array}{l}\text { Final concentration } \\
\left(\mathrm{mmol} \mathrm{l}^{-1}\right)\end{array}$ & $\begin{array}{l}\text { Relative activity } \\
(\%)\end{array}$ \\
\hline None & - & 100 \\
EDTA & 2 & 107 \\
$\mathrm{CaCL}_{2}$ & 2 & 97 \\
& 10 & 97 \\
& 50 & 84 \\
$\mathrm{Cu} \mathrm{SO}_{4}$ & 100 & 76 \\
$\mathrm{ZnSO}_{4}$ & 2 & 95 \\
$\mathrm{MgSO}_{4}$ & 2 & 95 \\
$\mathrm{MnCl}_{2}$ & 2 & 99 \\
$\mathrm{CoSO}_{4}$ & 2 & 102 \\
$\mathrm{Mix}^{*}$ & 2 & 97 \\
\hline
\end{tabular}

*Each metal ion at $2 \mathrm{mmol}^{-1}$.

$\dagger 100 \%$ activity $=226 \cdot 75$ units $\mathrm{ml}^{-1}$.

the enzyme was inactivated at $60^{\circ} \mathrm{C}$. Pectin lyase activity was observed in the $\mathrm{pH}$ range $5 \cdot 6-8 \cdot 6$, with optimum activity at 7.9. Addition of EDTA and metal ions to the reaction mixture had little effect on PL activity. A weak inhibitory effect was only seen in the presence of $\mathrm{CaCl}_{2}$ at 50 and $100 \mathrm{mmol} \mathrm{l}^{-1}$ (Table 2). $\mathrm{K}_{\mathrm{m}}$ and $\mathrm{V}_{\max }$ values, calculated by double reciprocal plots (Lineweaver and Burk 1934), were $4 \cdot 6 \mathrm{mg} \mathrm{ml}^{-1}$ and $94 \cdot 010^{-8} \mathrm{~mol} \mathrm{~min}^{-1} \mathrm{ml}^{-1}$, respectively.

\section{DISCUSSION}

Endophytic bacteria have been found in a variety of tissue types within numerous plant species, as reviewed by Kobayashi and Palumbo (2000), suggesting a ubiquitous existence in most if not all higher plants. Nevertheless, there is only one report on endophytic bacteria isolated from coffee roots and stems (Jimenez-Salgado et al. 1997). Here, an endophytic bacterium was isolated from surface-sterilized coffee cherries for the first time.

It was not surprising that pectinolytic micro-organisms were isolated from ripe cherries, as coffee cherry mucilage consists largely of pectic substances (Wootton 1963). However, according to Tsuyumu and Chatterjee (1984), pectin lyases have been detected in various fungi, but rarely in bacteria. As far as is known, isolate F 7-4 is the first strain of $P$. amylolyticus that produces extracellular PL.

Pectin lyase produced by isolate F 7-4 showed the same substrate specificity as Pseudomonas fluorescens (Schlemmer et al. 1987). Enzyme thermostability, the effect of temperature on PL activity, and $\mathrm{pH}$ of maximal PL activity, were similar to results reported for other bacterial and fungal PLs (Itoh et al. 1982; Parini et al. 1988; Silva et al. 1993). However, unlike Bacillus spp. (Kashyap et al. 2000), isolate F 7-4 PL was not activated by calcium ions. The $K_{m}$ value for isolate F 7-4 PL is not significantly different from that reported for pectin lyase from Ps. fluorescens $\left(3.2 \mathrm{mg} \mathrm{ml}^{-1}\right)$ (Schlemmer et al. 1987).

Pectin lyase was produced by isolate F 7-4 after $18 \mathrm{~h}$ of growth on a simple mineral medium, with only $0.3 \%$ pectin as inducer and carbon source. The enzyme has potential for use in studies on plant tissue maceration, natural fibre de-gumming and fruit juice wastewater treatment. The isolate is a promising tool for PL regulation studies, as pectinases and cellulases of some bacterial endophytes are induced for penetration into host plants but never after internal tissue colonization, as reviewed by Hallman et al. (1997).

\section{ACKNOWLEDGEMENTS}

The authors thank the Brazilian Agencies $\mathrm{CNPq}$ and FAPEMIG for their financial support. They are grateful to Leonardo Miranda Damasceno and Ann Honor Mounteer for reviewing this manuscript.

\section{REFERENCES}

Alanã, A., Llama, M.J. and Serra, J.L. (1991) Purification and some properties of the pectin lyase from Penicillum italicum. FEBS Letters 280, 335-340.

Albersheim, P. (1966) Pectin lyase from fungi. In Methods in Enzymology Vol. 8, ed. Neufeld, E.F. and Ginsburg, V. pp. 628-635. New York: Academic Press.

Alkorta, I., Garbisu, C., Llama, M.J. and Serra, J.L. (1998) Industrial applications of pectic enzymes: a review. Process Biochemistry 33, 21-28.

Ash, C., Priest, F.G. and Collins, M.D. (1994) Molecular identification of rRNA group 3 bacilli (Ash, Farrow, Wallbanks and Collins) using a PCR probe test. Proposal for the creation of a new genus Paeni bacillus. Antonie Van Leeumenhoek 64, 253-260.

Bacon, W.C. and Hinton, D.M. (1997) Isolation and culture of endophytic bacteria and fungi. In Manual of Environmental Microbiology ed. Hurst, C., Knudson, G.R., McInerney, M., Setzenbach, L. and Walter, M.V. pp. 413-421. ASM, Washington, DC, USA.

Baracat-Pereira, M.C., Coelho, J.L.C. and Silva, D.O. (1994) Production of pectin lyase by Penicillium griseoroseum cultured on sucrose and yeast extract for degumming of natural fibres. Letters in Applied Microbiology 18, 127-129. 
Hallmann, J., Quardt-Hallmann, A., Mahaffee, W.F. and Kloepper, J.W. (1997) Bacterial endophytes in agricultural crops. Canadian Fournal of Microbiology 43, 895-914.

Hayashi, K., Inoue, Y., Shiga, M. et al. (1997) Pectinolytic enzymes from Pseudomonas marginalis MAFF 03-01173. Phytochemistry 45, 1359-1363.

Henriksson, G., Akin, D.E., Slomczynski, D. and Eriksson, K.E.L. (1999) Production of highly efficient enzymes for flax retting by Rhizomucor pusillus. Fournal of Biotechnology 68, 115-123.

Hurek, T., Reinhold-Hurek, B., Van Montagu, M. and Kellenberger, E. (1994) Root colonization and systemic spreading of Azoarcus sp. Strain BH72 in grasses. Fournal of Bacteriology 176, 1913-1923.

Itoh, Y., Sugiura, J., Izaki, K. and Takahashi, H. (1982) Enzymological and immunological properties of pectin lyases from bacteriocinogenic strains of Erminia carotovora. Agriculture Biological Chemistry 46, 199-205.

Jimenez-Salgado, T., Fuentes-Ramirez, L.E., Tapia-Hernandez, A. et al. (1997) Coffea arabica L., a new host plant for Acetobacter diazotrophicus, and isolation of other nitrogen-fixing Acetobacteria. Applied and Environmental Microbiology 63, 3676-3683.

Jukes, T.H. and Cantor, R.R. (1969) Evolution of protein molecules. In Mammalian Protein Metabolism ed. Munro, H.N. pp. 21-132. New York: Academic Press.

Kashyap, D.R., Chandra, S., Kaul, A. and Tewari, R. (2000) Production, purification and characterization of pectinase from a Bacillus sp. DT7. World Journal of Microbiology and Biotechnology 16, 277-282.

Kobayashi, D.Y. and Palumbo, J.D. (2000) Bacterial endophytes and their effects on plants and uses in agriculture. In Microbial Endophytes ed. Bacon, C.W. and White, J.F., Jr. pp. 199-233. New York: Marcel Dekker Inc.

Lineweaver, H. and Burk, D. (1934) The determination of enzyme dissociation constants. Fournal of the American Chemical Society 50, 658-666.

Miller, G.L. (1959) Use of dinitrosalicylic acid reagent for determination of reducing sugar. Analytical Chemistry 31, 426-428.

Moran, F., Nasuno, S. and Stan, M.P. (1968) Extracellular and intracellular polygalacturonic acid trans eliminase of $E$. carotovora. Archives of Biochemistry and Biophysics 123, 298-306.

Murray, R.G.E., Doetsch, R.N. and Robinow, C.F. (1994) Determinative and cytological light microscopy. In Methods for General and
Molecular Bacteriology ed. Gerhardt, P., Murray, R.G.E., Wood, W.A. and Krieg, N.R. p. 26. Washington: American Society of Microbiology.

Nakamura, L.K. (1984) Bacillus amylolyticus sp. nov., nom. rev., Bacillus lautus sp. nov., nom. rev., Bacillus pabuli sp. nov., nom. rev. and Bacillus validus sp. nov., nom. rev. International fournal of Systematic Bacteriology 34, 224-226.

Parini, C., Fortina, M.G. and Manachini, P.L. (1988) Properties of two pectin lyases produced by Aureobasidium pullulans LV 10. Fournal of Applied Bacteriology 65, 477-481.

Prade, R.A., Zhan, D., Ayoubi, P. and Mort, A.J. (1999) Pectins, pectinases and plant-microbe interactions. Biotechnology and General Engineering Reviem 16, 361-391.

Quadt-Hallmann, A., Benhamou, N. and Kloepper, J.W. (1997) Bacterial endophytes in cotton: mechanisms of entering the plant. Canadian Fournal of Microbiology 43, 577-582.

Reinhold-Hurek, B. and Hurek, T. (1998) Life in grasses: diazotrophic endophytes. Trends in Microbiology 6, 139-144.

Saitou, N. and Nei, M. (1987) The neighbor-joining method: a new method for reconstructing phylogenetic trees. Molecular Biological Evolution 4, 406-425.

Schlemmer, A.F., Ware, C.F. and Keen, N.T. (1987) Purification and characterization of a pectin lyase produced by Pseudomonas fluorescens W51. Journal of Bacteriology 169, 4493-4498.

Shida, O., Takagi, H., Kadowaki, K., Nakamura, L.K. and Kogamata, K. (1997) Emended description of Paenibacillus amylolyticus and description of Paenibacillus illinoisensis sp. nov. and Paenibacillus chibensis sp. nov. International Fournal of Systematic Bacteriology 47, 299-306.

Silva, D.O., Attwood, M.M. and Tempest, D.W. (1993) Partial purification and properties of pectin lyase from Penicillium expansum. World Journal of Microbiology and Biotechnology 9, 574-578.

Smibert, R.M. and Krieg, N.R. (1994) Phenotypic characterization. In Methods for General and Molecular Bacteriology ed. Gerhardt, P., Murray, R.G.E., Wood, W.A. and Krieg, N.R. pp. 607-654. Washington: American Society for Microbiology.

Tsuyumu, S. and Chatterjee, A.K. (1984) Pectin lyase production in Erminia chrysanthemi and other soft-rot Erminia species. Physiological Plant Pathology 24, 291-302.

Wootton, A.E. (1963) The Fermentation of Coffee. Report no. 12. Nairobi, Kenya: East African Industrial Research Organization. 